ANADOLU, J. of AARI

ISSN: 1300-0225 (Print)

E-ISSN: 2667-6087 (Online)

2020, 30 (1): 103-116

DOI: $10.18615 /$ anadolu. 727258

\title{
Bal Arılarında (Apis mellifera L.) Beslenmenin Hastalık ve Zararlılarla İlişkisi
}

\author{
Tuğçe OLGUN ${ }^{1^{*}}$ (D) Erkan TOPAL ${ }^{2}$ (D) Nazmiye GÜNEŞ ${ }^{3}$ \\ Devrim OSKAY ${ }^{4}$ (D) Aybike SARIOĞLU ${ }^{5}$
}

\author{
${ }^{1,2}$ Ege Tarımsal Araştırma Enstitüsü, Menemen-İzmir/TÜRKiYYE \\ ${ }^{3,5}$ Uludă̆ Üniversitesi, Veteriner Fakültesi, Biyokimya Bölümü, Bursa/TÜRKiYE \\ ${ }^{4}$ Tekirdă̆ Namık Kemal Üniversitesi, Ziraat Fakültesi, Tarımsal Biyoteknoloji Bölümü, Tekirdăğ/TÜRKiYE
}

\author{
${ }^{1}$ https://orcid.org/0000-0003-2386-1244 $\quad{ }^{2}$ https://orcid.org/0000-0002-1398-4390 \\ ${ }^{3}$ https://orcid.org/0000-0002-8096-1316 $\quad{ }^{4}$ https://orcid.org/0000-0002-3410-2780 \\ ${ }^{5}$ https://orcid.org/0000-0002-8287-6617 \\ *Corresponding author (Sorumlu yazar): tugce.olgun@tarimorman.gov.tr \\ Received (Geliş tarihi): 03.10.2019 Accepted (Kabul tarihi): 09.01.2019
}

ÖZ: Son yıllarda yaşanan yoğun bal arısı (Apis mellifera L.) ölümleri arıcılıkta birçok konunun sorgulanmasına neden olmaktadır. Arı sağlı̆̆ına yönelik kimyasalların kullanımının beklenen sonuçları tam olarak vermemesi ve arı ürünlerinde kalıntı sorunu gibi yeni sorunları ortaya çıkarması nedeniyle yeni çıkıs yolları aranmaktadır. Yapılan çalışmalarda arıların birçok stres faktörleri ile baş edememesinin nedenlerinden birisi olarak arıların yeterli ve kaliteli besin kaynakları ile beslenememesi olduğu düşünülmektedir. Yetersiz beslenme neticesinde, bal arısı immün sisteminin zayıflamasıyla yaygın görülen arı hastalık ve zararlılarına hedef olmaktadırlar. Arıların besin durumunun iyileştirilmesinin, arı sağlığına yönelik zorluklarla mücadelede temel amaç olması gerektiğinin arıcılar tarafindan iyi anlaşılması sürdürülebilir arıcılık açısından önemlidir. Bu derleme ile mevcut araştırmalar ve yeni bilgiler ışı̆̆ında bal arılarında beslemenin önemi ortaya konarak, arıcılar tarafindan iyi anlaşılması hedeflenmiştir.

Anahtar Kelimeler: Bal arısı, Apis mellifera L., beslenme, arı sağlı̆̆ı, protein, virüs, protozoa, parazit.

\section{The Relationship Between Nutrition and Diseases and Pests in Honey Bees (Apis mellifera L.)}

\begin{abstract}
In recent years, intensive honey bee (Apis mellifera L.) deaths have caused many questions in beekeeping. As the use of chemicals for bee health does not give the expected results and new problems such as residue problems in bee products are emerging, new ways of exit are being sought. In the studies, it is foreseen that the bees cannot cope with many stress factors and that the bees are not fed with sufficient and high-quality food sources. As a result of malnutrition, honey bee is the target of common bee diseases and pests due to decreased the immune system, It is important in terms of sustainable beekeepers to be well understood by beekeepers that improving the nutritional status of bees should be the main objective in fighting against bee health challenges. With this review, in the light of current researches and new information, the importance of feeding honey bees is revealed and it is aimed to be well understood by beekeepers.
\end{abstract}

Keywords: Honey bee, Apis mellifera L., nutrition, bee health, protein, virus, protozoa, parasit. 


\section{GíRiş}

Arılar tarım alanlarında ve doğal bölgelerde çiçekli bitkilerin en önemli tozlayıcılarıdır. Bal arıları (Apis mellifera L.) koloni formunda yaşayan ve tarım alanlarında polen ve nektar toplamaya adapte olmuş sosyal böceklerdir. Birleşmiş Milletler Gıda ve Tarım Örgütü (FAO) doğrudan tozlayıcılara dayanan küresel mahsullerin fiyatının y1lda 235 dolar ile 577 milyar dolar arasında olduğu tahmin edildiği bildirilmektedir (Da Silva, 2018). Fakat son yıllarda Dünya'da arıların populasyonu giderek azalmaktadır. Özellikle bal arısı kolonilerindeki kayıplar yaklaşık olarak Amerika Birleşik Devletleri'nde 2006 yılından bu zamana \% 40, Avrupa'da 1985 yilından beri $\%$ 25, İngiltere'de 2010 yılından beri \% 45'e ulaşmıştır (Potts ve ark., 2010; Allsopp ve ark., 2014; Traynor ve ark., 2016; Karacoban, 2018).

İklim değişimi sıcaklık ve nem dalgalanmalarına neden olmakta, bunun sonucu bitkilerin fizyolojik faaliyetleri (nektar ve polen salgılama, çiçeklenme vb.) olumsuz etkilenmekte, hatta bazı bitkiler yok olmakta, sonuçta bal arılarında koloni kayıpları meydana gelebilmektedir (Winston, 1987; Thuiller ve ark., 2005; Oskay, 2017). İklim değişikliği ve bundan kaynaklanan yağmur ve güneş radyasyon yoğunluğu arıların uçuş aktivitesi, bal depolaması, kraliçe arıların yumurtlaması gibi fizyolojik özelliklerini olumsuz yönde etkilemektedir (Szabo, 1980; Burrill ve Dietz, 1981; Heard ve Hendrickz, 1993; Alhaddad ve Darchen, 1995; Vicens ve Bosch, 2000; Kasper ve ark., 2008; Switanek ve ark., 2017). İklim değişikliği ile birlikte son yıllarda koloni çöküşlerinin, çevresel stres kaynaklarından, yem-beslenme açığından, parazit ve patojenlerden de kaynaklandığı ifade edilmektedir (Naug, 2009; Gumusova ve ark., 2010; VanEngelsdorp ve Meixner, 2010; Dolezal ve Toth, 2018 Morawetz ve ark., 2019).

ABD'de 2006'nın sonlarından bu yana Koloni Çöküş Sendromundan dolayı (KÇS) her yıl \% 3040 arı kolonisi kaybı bildirilmektedir (Ellis, 2007; VanEngelsdorp ve ark., 2010).

KÇS'nin nedeni tam olarak bilinemese de birçok bilim insanı bunun pestisitler, parazitler, tarım arazileri kaybı neticesinde yaşanan habitat kaybı, beslenme stresi ve uzun mesafeli taşınmadan kaynaklanan stres faktörleri nedeniyle oluşabileceğini düşünmektedir (Oldroyd, 2007; Cox-Foster ve ark., 2009; Naug, 2009). Beslenme yetersizliği, bağışıklık sistemini hem bireysel hem de koloni düzeyinde zayıflatabildiğinden diğer faktörlerin etkilerini şiddetlendirebilir (Huang, 2012). Örneğin Morimoto ve ark. (2011), seralarda kısıtll çiçek türlerinde uzun süreli tozlaşma için kullanılan bal arılarında k1sıtlı beslenmeden dolayı indüklenen immun baskılama ve oksidatif stresin gen ifadesini değiştirdiğini bildirmişlerdir. Yapılan çalışmalarda son zamanlarda koloni kayıplarında artış gözlendiği ve bu kayıpların beslenme yetersizliğinden kaynaklandığı belirtilmektedir.

$\mathrm{Bu}$ derleme; hastalık ve zararlıların neden olduğu koloni kayıplarına karşın, ek besin takviyesi uygulamaları ile koloninin immun sisteminin güçlendirmesi amacıyla hazırlanmıştır.

\section{KOLONININ İMMUN SISSTEMİ ve BESLENME İLIŞKİSI}

Koloni kayıplarının oluşumuna neden olan stres faktörlerinden virüsler ve diğer patojenler, sosyal böcek kolonilerinde besin alışverişi esnasında, bireyler arasında, yakın temas ile hızla yayllabilmektedir. Koloni ve bireysel immun sistemi ile koloninin beslenme durumu arasında önemli bir ilişki vardır. Eğer koloninin varroa parazit yükü yüksek ise, koloni bireyleri alarma geçerek bitkilerden resin (propolis) toplar ve propolis içerisinde bulunan bileşikler sayesinde antimikrobiyal ve antiviral zarf (kovan içerisindeki propolis kitleleri) oluşturur. Bazı bileşikler varroanın gelişmesini baskılarken, $p$-kumarik gibi bileşikler immun sistem genlerinin daha aktif olmasını sağlamaktadır. Fakat DeGrandi-Hoffman ve Chen (2015), parazitik varroa akarları, arıların besin seviyesi azaldığı zaman bireysel bağışıklık fonksiyonunu baskılar, bunun sonucu koloni diğer hastalıklara açık hale geldiğini bildirmektedir (Şekil 1). 


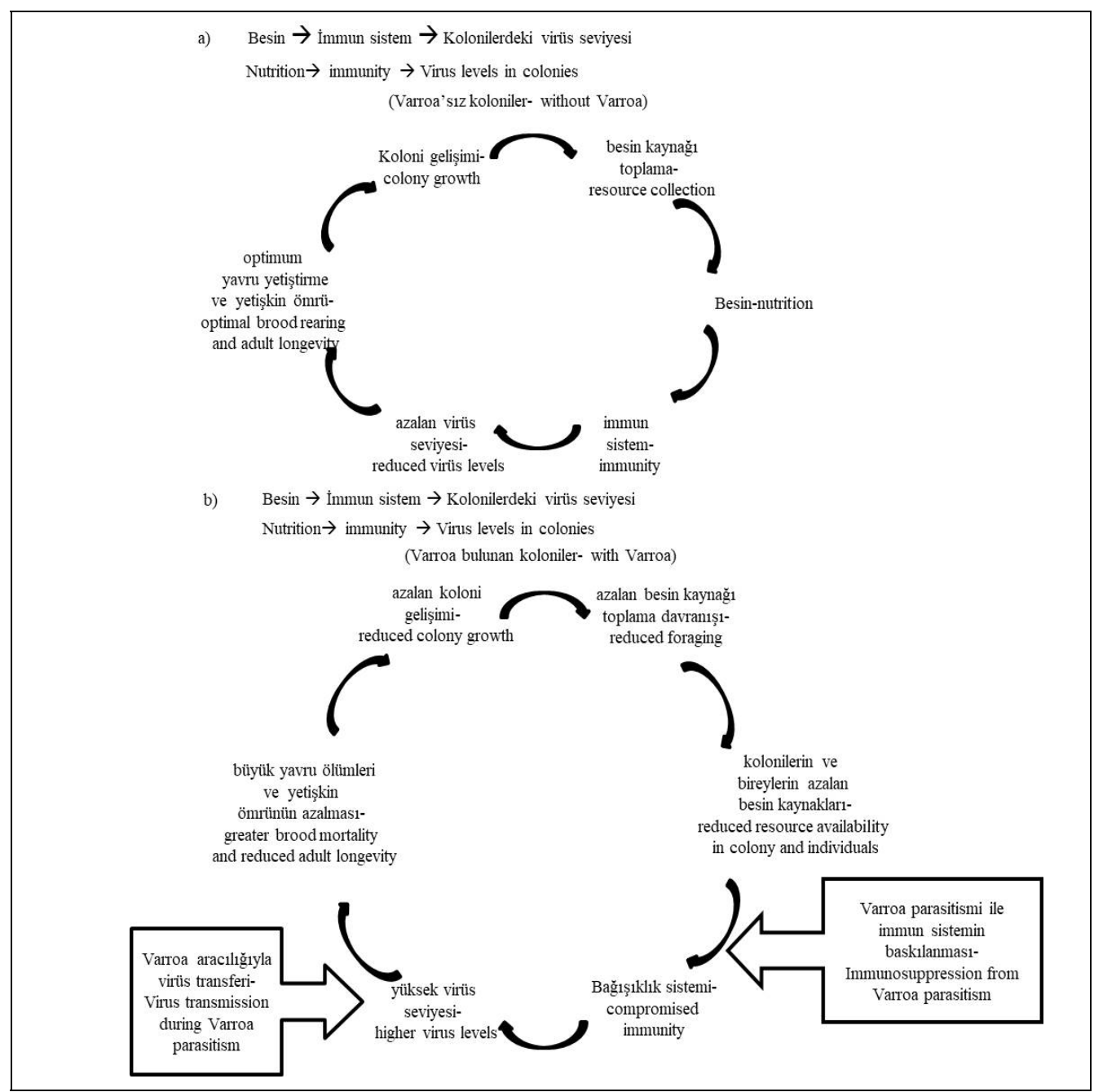

Şekil 1. Besin, immun sistem ve virüs seviyesi arasındaki ilişkilerin ve koloni gelişimi üzerindeki etkilerinin şeması (a) ve arıların Varroa akarları ile parazitlendiği zamanki ilişkilerindeki değişimler (b) (DeGrandi-Hoffman ve Chen, 2015).

Figure 1. Schematic of the relationships among nutrition, immunity and virus levels and the effects on colony growth (a) and changes in the relationships when bees are parasitized by Varroa mites (b) (DeGrandi-Hoffman ve Chen, 2015).

Yeterli ve kaliteli beslenme koloni, yetişkin, larvaların beslenmesi ve gelişiminin devamı için oldukça önemlidir (Brodschneider ve Crailsheim, 2010). Bir araştırmada; polen ve nektarda bulunan çeşitli makro (protein, karbonhidrat ve yağlar) ve mikro besin elementlerinin (steroller, mineraller ve vitaminler) karışımını içeren karmaşık diyetler kullanmak yerine şeker ve aminoasitler [Esansiyel aminoasitler: L-arginine $\mathrm{HCl}$, L-histidine, Lisoleucine (allo içermeyen), L-leucine (methionine içermeyen), L-lysine monohydrochloride, Lmethionine; L-phenylalanine, L-threonine (allo içermeyen), L-tryptophan; and L-valin ve
Esansiyel olmayan aminoasitler: L-alanine, Laspartic acid, L-cystine, glycine hydrochloride, Lglutamic acid (monosodyum), L-proline (hydroxy L-proline içermeyen), L-serine, tyrosine] içeren bir diyet kullanılmıştır. Çünkü arılar tarafından toplanan sadece arginin içeren karahindiba/ Taraxacum buttleri Soest. (Herbert ve ark., 1970) ve histidin içeren misır (Höcherl ve ark., 2012) gibi yetersiz amino asit içeren bitkilerin polenleri kolonilerde kuluçka üretiminin zayıf olmasına neden olmaktadır (Loper ve Cohen, 1987). Hendriksma ve ark. (2019) tarafından kafeslerde yürütülen bir araştırmada gerekli amino asitler ile beslenen 
arıların gelişiminde ve bakıcı arıların baş (hipofaringial kuluçka besleme bezinin gelişmesinden dolayı) ve toraks (uçuş kas gücünün artmasından dolayı) ağırlıklarında belirgin bir artış gözlenmiştir. Bakıcı arıların bu özelliklerinin, koloni gelişimi ve kuluçka bakımını olumlu yönde etkilediği sonucuna varılmıştır (Hendriksma ve ark., 2019).

Diyetlerdeki protein eksikliği immün sistemin zayıflamasina neden olabilir. Protein ile beslenen arılarda hem bireysel hemde sosyal immün yeteneği değişirken, diyet protein oranındaki artışların immün yeteneği arttırmadığı belirlenmiştir. Bunun yanında polifloral polenin protein kaynağı olarak yeterli aminoasit çeşitliliğinin yanısıra esansiyel amino asitler yönünden de yeterli olduğu, bu beslenme şeklinin immün yeteneği arttırdığg ve özellikle de monofloral ile karşılaştırıldığında polifloral diyetlerin daha yüksek glikoz oksidaz (GOX) aktivitesine neden olduğu belirlenmiştir (Alaux ve ark., 2010). Polifloral polenlerin, bağışıklığ ${ }_{1}$ arttırarak arıları strese karşı daha dayanıklı hale getirdiği ifade edilmektedir. Koloni düzeyinde polen ile beslenmenin iyi olmasi bal arisinin Nosema ceranae ve varroaya karşı direncini arttırmaktadır. Koloni nakilleri ve flora değişimlerinin, bal arıları üzerindeki etkileri kolonilerdeki polen çeşitliliği veya miktarıdır. Yetersiz beslenme, bal arısı kolonilerini etkileyen çevresel streslerden sadece biridir. Ancak, hastalık ve zararlılar ile diğer çevresel stres kaynaklarının (patojenler, virüsler, funguslar ve kimyasallar) etkilerine yönelik hazırlayıc1 en önemli faktördür (Huang, 2012). Di Pasquale ve ark. (2013), tarafından yürütülen ve polen diyetlerinin kalite ve çeşitliliğinin arı sağlığına etkisinin belirlendiği bir çalışmada hem bakıcı arı fizyolojisinin hem de parazite karşı toleransının polen kalitesinden etkilendiği tespit edilmiştir. Parazitlendiğinde, polifloral polenle (karışı) beslenen arıların, protein bakımından zengin monofloral (kestane, funda) polen hariç, monofloral (pamucak, funda) polenlerle beslenen arılardan daha uzun yaşadığı tespit edilmiştir. Araştırmacılar polenin kalite ve çeşitliliğinin büyük oranda arı fizyolojisi üzerine etkili olduğunu belirtmektedirler.

\section{VARROA ve BESLENME İLISSKISII}

Dünya'da bal arısı sağlığını etkileyen en büyük nedenlerinden birisi parazitik akar Varroa destructor'dur. Yürütülen bir çalışmada bilinenin aksine varroanın bal arısının hemolenf tüketmediği, ama hormonal sistemde, immun cevapta ve özellikle pestisit detoksifikasyonunda önemli role sahip olan yağ dokusuna zarar verdiği belirlenmiştir (Arrese ve Soulages, 2010; Ramsey ve ark., 2019). Ramsey ve ark. (2019), üreme dönemlerinde hemolenf ile beslenen grubun aç birakılan kontrol grubundan bir fark1 olmadığını belirlemişlerdir. Ancak araştırıcılar yağ doku ile beslenen akarların daha uzun hayatta kaldığını ve daha fazla yumurta bıraktığını tespit etmişlerdir. Sonuçta akarların yă̆ dokuyu birincil besin kaynağı olarak kullandığı belirlenmiştir.

Zarar görmemiş yağ dokusu, arıların sağlıklı bir kış dönemi geçirmesi açısından oldukça önemlidir. Bunun en büyük nedeni, oksidatif stresi azaltarak arıların yaşam süresini uzatmakta önemli olan vitellogeninin, yağ dokusundan üretilmesi ve depolanmasidır (Amdan ve ark., 2003; 2004). Dolayısıyla kışlama öncesi, varroa yükü koloninin geleceğine olumsuz etki etmektedir. Aynı zamanda kış döneminde yaşanan sıcaklık değişimleri bitki fenolojisini (gelişme safhalarını) ve koloni durumunu olumsuz etkilerken varroanın etkinliğini arttırmakta, dolayısıyla koloni sağlığını bozmaktadır (Nürnberger ve ark., 2019). Varroa özellikle arı pupaları üzerinde zararlı olup metamorfoz sirasinda görülen fizyolojik ağırlık kaybının düzenli olarak artmasına neden olmaktadır. Aronstein ve ark. (2012), varroa ile istila edilen ergin arıların ve pupaların ağırlıklarının baskılandığını, birçok besin maddesinin (protein, trehalose) yoğunluğunun azaldığını gözlemlemişlerdir. Varroa kaynaklı yaşanan bu kaybın, ilkbahar döneminde yapılan polifloral polen takviyesi durumunda azaldığ 1 bildirilmektedir (Janmaat ve Winston, 2000; Huang, 2012; Piou ve ark., 2018). Polifloral polenin özellikle glukoz oksidaz aktivitesi ve 
kovan içinde antiseptik koruma özelliğinin olmasından dolayı arıcılar tarafindan ek takviye besin maddesi olarak kullanılması önerilmektedir (Huang, 2012).

\section{BAKTERIYEL HASTALIKLAR ve BESLENME ÍLIŞKISİ}

Önemli arı kayıpları sonucu ciddi ekonomik kayıplara neden olan ve yavru çürüklüğü olarak belirti gösteren Amerikan yavru çürüklüğü (gram pozitif bakteri Paenibacillus larvae) (Genersch, 2010) ve Avrupa yavru çürüklüğü (gram pozitif bakteri Melisococcus plutonius) (Arai ve ark., 2012) olarak adlandırılan iki önemli bakteriyel hastalık bulunmaktadır. Çevre koşullarına dayanıklı olan bu bakteriyel hastalıkların sporlarının hücre duvarlarına zarar vererek geçirgenliğini değiştiren yağ asitleri, önemli antimikrobiyel bir besin kaynağıdırlar (Ababouch ve ark., 1992; Kuzyšinová ve ark., 2016). Antimikrobiyel özelliği olan birçok yağ asitlerinden özellikle; linolenik, linoleik ve dodekanoik asitlerin yüksek antimikrobiyel konsantrasyona sahip olduğu tespit edilmiştir (Manning, 2001). Bu bakımdan polen önemli bir yağ asiti kaynă̆ıdır. Yapılan bir çalışmada polenlerden izole edilen 40 adet doymuş ve doymamış yağ asidi analiz edilmiş, bunların 24 tanesinin $P$. larvae inhibe edici aktivitesinin pozitif sonuçlar verdiği ve bunların içerisinde laurik, palmitoleik ile linoleik asitlerin en yüksek aktiviteye sahip olduğu belirlenmiştir (Feldlaufer ve ark., 1993). Hornitzky (2003), 28 yağ asidinden $P$. larvae etmenine karș1 15'inin yüksek aktivite gösterdiğini (undekanoik, laurik, kaproik, homo--r-linolenik, s-linolenik, risinoleik, linoleik, linolenik, arakhidonik ve myristik asit), sekizinin (özellikle undekanoik, laurik, homo-slinolenik, risinoleik ve myristik asit) ise $M$. plutonius etmenine karşı antibakteriyel özellikte olduğunu tespit etmiştir. Polenlerden elde edilen bu yağ asitleri kovan içi hijyende önemli rol oynamaktadır (Manning, 2001). Özellikle yavru gözlerinin bulunduğu peteklere depolanan polenlerden yağ asitlerinin yavrulu gözlere sızıntı yapması ile mikroorganizmaların vejetatif büyümesi ve sporların gelişimi baskılanarak yavru gözlerinin sterilizasyonunun sağlandığ1 düşünülmektedir (Manning, 2001; Kuzyšinová ve ark., 2016). Bu nedenle yağ asidi konsantrasyonları yüksek olan polenlerin mevcut olduğu bölgelere kovanların taşınması yavru çürüklüğüne neden olan sporların üremesini baskılaması açısından önem arz etmektedir (Manning, 2001). Aynı tür polen kaynağı içeren bölgelerde arıcılık yapılması hem arıların tek lipit kaynaklı polenle beslenmesine (monofloral) hem de besinsel anlamda yüksek yağ asitleri içeren polenlerden mahrum kalmasına neden olabilecektir.

\section{VIRAL HASTALIKLAR ve BESLENME İLIŞKISISI}

Son yıllarda yüksek miktarda koloni kaybı ve bazı coğrafyalarda yerli ve yabani arı populasyonlarının azalması, uygun fiyatlı gıda ürünleri varlığını, yerli ve yabani bitki türlerinin çeşitliliğini ve bolluğunu etkilemektedir. Bu azalmanın olumsuz sonuçları sadece bunlar değildir. Patojenlerin artışı, tarımsal kimyasallar, iklim değişikliği, kuraklık, yetersiz habitat ve beslenme kaynakları gibi birçok faktöre bağlanırken, özellikle virüs kaynaklı hastalıkların artışı, bal arısı kolonisi kayıpları, yerli ve yabani arılardaki bireysel ölüm ve hastalıklar ile ilişkilendirilmektedir. McMenamin ve Flenniken (2018), spesifik viral suşları tanımlamaya ve arı sağlığı üzerindeki etkilerini ortaya koymaya çalışmışlardır. Bal arılarında 30'dan fazla virus tespit edilirken, birkaçı da diğer arı türleri ve karıncalarda tespit edilmiştir. En s1k incelenen bal arıs1 RNA virüsleri, Akut Ar1 Paralizi Virüsü (ABPV), Keşmir Arı Virüsü (KBV), İsrail Akut Paralizi Virüsü (IAPV), Kara Kraliçe Hücre Virüsü (BQCV), Kronik Ar1 Paralizi Virüsü (CBPV), Deforme Kanat Virüsü (DWV) ve Tulumsu Yavru Çürüklüğü Virüsüdür (SBV). Bildirilen diğer virüsler arasında ise Kakugo Virüsü (KV), Varroa Destructor Virus-1 (VDV-1) Arı Virüsü X (BVX), Arı Virüsü Y (BVY), Bulutlu Kanat Virüsü (CWV), Yavaş Arı Paralizi Virüsü (SBPV), Arı Virüsü (ABV), Makula Benzeri Virüs (MaLV), Berkeley Ar1 Virüsü (BBV), Tayland Yavru Çürüklüğü Virüsü (TSBV), Yaprak Biti Öldürücü Felç Virüsü 
(ALPV), Büyük Sioux Nehri Virüsü (BSRV) ve Sina Gölü Virüsü (LSV-1 / LSV-2) bulunur (McMenamin ve Flenniken, 2018).

Beslenme kalitesi hastalıklara karşı direncin artmasını sağlamaktadır. Şeker şurubu ile beslenen arıların yaşlandıkça düşük protein içerikli polen ile beslenen arılara göre daha küçük hipofarenks bezlere sahip olduğu ve virüs yükünün arttığ 1 tespit edilmiştir. Yapılacak ek besleme ile protein stresinin azaltılabileceği bildirilmiştir (DeGrandiHoffman ve ark., 2010). Yüksek kaliteli polen kaynaklarının (polifloral / monofloral) İsrail akut felç virüsü (IAPV) enfeksiyonunda ölümleri azalttığ belirlenmiştir. Özellikle akut felç virüs enfeksiyonu ve düşük kaliteli polenle yetersiz beslenme nedeniyle, arılarda oluşan aşırı stresin arıların kovan dışına çıkma davranışını arttırdı̆̆ ifade edilmiştir. Sonuç olarak Dolezal ve ark. (2019), doğru beslenme ile bal arıları virüslerin olumsuz etkilerinden korunabildiğini ifade etmektedirler.

\section{NOSEMA ve BESLENME İLIŞKİSI}

Yaygın parazit Nosema spp.'nin neden olduğu enfeksiyonun bal arılarının fizyolojisini, davranışını ve hayatta kalmasını etkilemektedir. Nosema enfeksiyonu midgut (orta bağırsak) bütünlügünü bozmakta ve organizmanın enerji gereksinimini değiştirmektedir. Enfeksiyon ayrıca bağışıklık tepkisini önemli ölçüde bastırırken işçi ve kraliçe bal arılarındaki feromon üretimini değiştirebilmektedir. Nosema'nın varlığ olarak koloni zayıflaması ve bal arısı ölümü ile ilişkili değildir. Nosema'nın etkisi diğer etkilerle birlikte ortaya çıkmaktadır. Nosema'nın etkisi, parazit veya konakçı genetiği, beslenme, iklim, çevresel kirleticiler veya diğer parazitler gibi diğer stres maddeleri ile etkileşime bağlıdır (Paris ve ark., 2018). Yeterli protein, karbonhidrat ve vitamin içeriği olan kaliteli besinlerin günümüz arıcılığının önemli sorunu olan bu stres faktörlerinin tolere edilmesine önemli katkıs1 vardır (Naug ve Gibbs, 2009; Brodschneider ve Crailsheim, 2010; Fleming ve ark., 2015). Bal arısının beslenmesi ile Nosema varlığındaki değişimi izlemek için yapılan bir çalışmada, laboratuvar ortamında bal arıları üç besin kaynağı (şurup - arı ekmeği - polen) ile beslenmiş ve Nosema 7. günden sonra aşılanmıştır. Nosema tüm gruplarda varlığını sürdürürüken en hızlı gelişimin polen grubunda olduğu tespit edilmiştir (Porrini ve ark., 2011). Arıların polen tüketimindeki artışın midgutda Nosema sporunun artmas1 ile doğru orantılı olduğu gözlenmiştir (Rinderer ve Elliott, 1977). Yakın geçmişte yapılan bir çalışmada da, bal arıları 4 farklı diyet (Nosema sporu içermeyen şeker solusyonu (kontrol), Nosema sporuyla aşılanmış polensiz şeker solüsyonu, Nosema sporuyla aşılanmış polen ilaveli şeker solüsyonu, Nosema sporuyla aşılanmış polen) ile beslenmiştir.

Fleming ve ark. (2015), Nosema sporuyla aşılanmış polen ilaveli beslemede Nosema spor seviyesinin diğer besleme gruplarına göre belirgin bir şekilde daha fazla yükseldiği gözlenmiştir (Şekil 2).

Rasyondaki besin maddesinin içeriği arıların bağışıklık tepkilerini etkileyerek patojenlere direnç göstermesini sağlamaktadır. Giacomini ve ark. (2018), ayçiçeği (Helianthus annuus) poleninin bombus arılarındaki (Bombus impatiens) protozoa (Crithidi bombi) enfeksiyonunu ciddi bir şekilde azalttığını ve ayrıca Avrupa bal arısında da (Apis mellifera) Nosema ceranae enfeksiyonunu azalttığını gözlemlemişlerdir. Polen kalitesinin Nosema ceranae patojenine karşı bal arılarının toleransına etkisini araştıran bir çalışmada, enfekte olmuş arıların yüksek protein ve antioksidan seviyesine sahip polen (örn. rubus türleri) ile beslenmesinin ömürlerini arttırdığı ortaya koyulmuştur (Di Pasquale ve ark., 2013). Ayrıca yüksek lipit içeriğine sahip olan ve yüksek vitellogenin üretimini destekleyen polenler (örn. kestane) yine parazit taşıyan arıların yaşam sürelerinin artmasını sağlayabileceği düşünülmektedir (Seehuus ve ark., 2006; Di Pasquale ve ark., 2013). Ar1 organizmas1, farkl1 mevsimlerde üretilen polenle karşılaştığı zaman farklı şekilde yanit vermektedir. İlkbahar ve sonbahar aylarında arıların polen sepetleriyle kovana getirilen ve polen tuzakları ile toplanmış polenlerin toplam protein ve lipid konsantrasyonlarının benzer olduğu, ancak ilkbahar polenlerinin hipofarengeal 
bezlerin (HPG) büyümesini ve kuluçka üretimini destekleyen daha yüksek amino ve yağ asitleri konsantrasyonlarına sahip olduğu tespit edilmiştir. Hem enfekte olmamış hem de Nosema ile enfekte olmuş ilkbahar polenleri ile beslenmiş arılarının HPG'si, sonbahar poleniyle beslenmiş arılara kıyasla (mevsimde) ilkbaharda beslendiklerinde daha büyük olduğu belirlenmiştir. Bahar arıları, mevsim dışı polen ile beslendiğinde 200 'den fazla genin farklı olarak düzenlendiği tespit edilmiştir. Nosema ile enfekte edildiğinde, yaklaşı 400 gen, polen tipine bağ lı olarak ilkbaharda arılarda farklı enfeksiyon kaynaklı ekspresyon modelleri göstermiştir. Buna karşılık, sonbahar arılarında HPG boyutu polen tipinden etkilenmemiş, ancak HPG, Nosema ile enfekte olanlarda daha küçük olmuştur. Çok az sayıda gen, enfekte edilmemiş (4 gen) ve enfekte olmuş arılardaki (5 gen) polen tipi ile farklı şekilde eksprese edilmiştir. Polen tipinin, sonbahar arılarında enfeksiyon kaynaklı ekspresyon modellerini etkilemediği belirlenmiştir. Mevsimsel polenlere verilen fizyolojik tepkilerin, özellikle de Nosema ile enfekte olduğunda polen tipine karşı daha duyarlı olan ilkbahar ve sonbaharda yetiştirilen arılar arasında farklılık gösterdiği ifade edilmektedir. DeGrandi-Hoffman ve ark. (2018) tarafından gerçekleştirilmiş olan bu çalışma, mevsimlik polenlerin, yıllık koloni döngüsünde bal arılarının aktiviteleriyle uyumlu besin seviyeleri sağlayabileceğine dair kanttlar sunmaktadır. Bulgular bal arılarının sürdürülebilirliği için yem bitkilerinin planlanması ve polen mevcut olmadığında kolonilere verilen mevsimsel besin takviyelerinin geliştirilmesi açısından önemlidir.

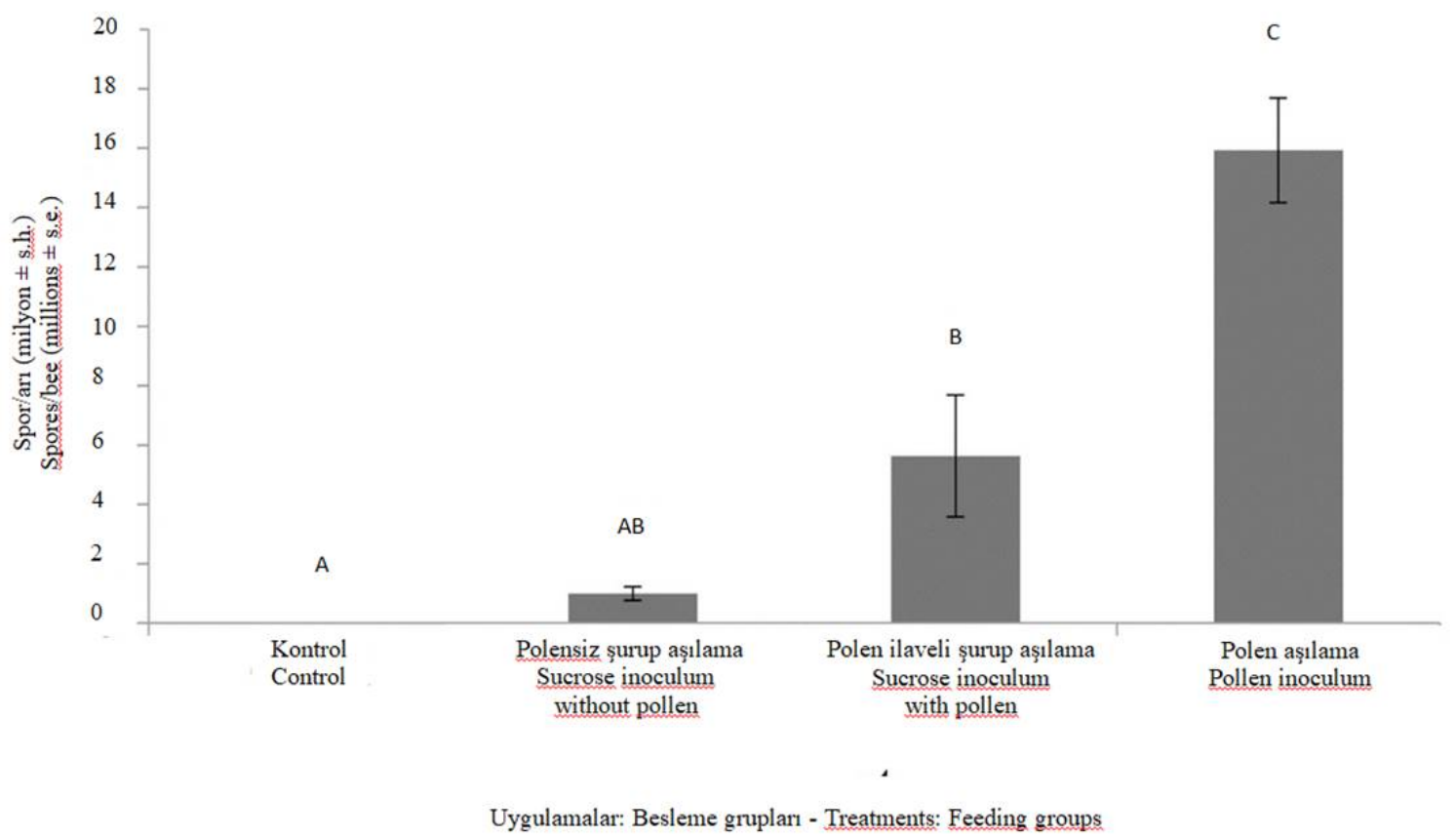

Şekil 2. Nosema seviyesindeki aşılama metotlarının arılarda etkisi. Beslenme grupları: (A) kontrol (aşılama olmadan şeker solüsyonu ile beslenmiş arılar), (AB) polensiz şurup aşılama (Şeker solüsyonu yoluyla Nosema ile aşılanan ve hiç polen verilmeyen arılar), (B) polenli surup aşılama (Şeker solüsyonu yoluyla Nosema ile aşılanan ve polen verilen arılar) ve (C) şeker solüsyonu ile polen aşılama (Polen yoluyla Nosema sporu aşılanmış arılar) (Fleming ve ark., 2015).

Figure 2. The impact of inoculation method on Nosema levels in bees. Treatments: (A) control (bees fed a sucrose solution, no inoculum), (AB) sucrose inoculum, no pollen (bees inoculated with Nosema through a sucrose solution and given no pollen), (B) sucrose inoculum, with pollen (bees inoculated with Nosema through a sucrose solution and given pollen), and (C) pollen inoculum, with sucrose solution (bees inoculated with Nosema through pollen) (Fleming et al., 2015). 
Parazitler genellikle, besin alım oranlarında değişikliklere neden olarak veya kendiliğinden bulaşmayı tetikleyerek, konaklarının tarlacılık davranışını değiştirirler. Nosema ceranae, Avrupa veya Batı bal arısının (Apis mellifera) enerji ihtiyaçlarını artırır. Yüksek kaliteli bir polene erişimi olan enfekte arıların, daha düşük kalitede bir polen veya polen içermeyen, enfekte olmuş arılara kıyasla hayatta kalma olasılıklarının daha yüksek olduğu tespit edilmiştir. Enfekte olmamış arılarda polen kalitesinin hayatta kalmayı etkilememiştir. Ferguson ve ark. (2018) tarafından yapılan bu çalışmaya göre, $N$. ceranae ile enfekte olmuş arıların polen kalitesinin artmasından yarar sağladıkları ve polen için yiyecek toplarken daha yüksek kaliteli polen tercih ettikleri, ancak enfeksiyonun birey ya da kovan seviyelerinde polen toplanması üzerine etkisi olmadığ 1 belirlenmiştir.

\section{ANTIOKSIDDANLAR ve BESLENME İLişKİsì}

Reaktif oksijen türleri (ROS), aerob (oksijene ihtiyaç duyan) canlıların metabolik işlemlerinde sürekli olarak üretildiğinden, organizma ROS miktarı ile antioksidan süreçler arasında bir denge kurmaya çalışmaktadır. ROS'un aşırı üretimi (oksidatif stres), lipidlerin peroksidasyonu, nükleik asit bozulmas1, proteinlerdeki amino asitlerin modifikasyonu, biyolojik aktivitelerini değiştirme gibi bazik moleküllerin zarar görmesine neden olabilmektedir (Farjan ve ark., 2012). Etkili bir antioksidan sistem, doğal olarak çok büyük miktarlarda serbest radikal üreten bir metabolizma hızına sahip böcekler için özel bir öneme sahiptir (Candy ve ark., 1997). Toplam antioksidan seviyesi (TAS) oksidasyona karşı koyma kabiliyetinin ölçüsüdür (Farjan ve ark., 2012).

Bal arıs1 genomunun diziliminin ortaya koyulmasından sonra antioksidan kapasitenin değerlendirilmesi daha kolay hale gelmiş olup buna dayanarak Corona ve ark. (2005), antioksidan proteinleri kodlayan en az 38 gen olduğunu belirtmiştir. Böceklerdeki en önemli antioksidan enzimler süperoksit dismutaz (SOD), katalaz (CAT), peroksidazlardır (POX) (Farjan ve ark., 2012).
Bal arısı antioksidan enzimleri, ana arının istisnai biyolojik özelliklerinden dolayı ve ayrıca işci arılara oranla uzun ömürlü olmalarını etkilemeleri nedeniyle önem taşımaktadır (Page ve Peng, 2001). Baz1 konvansiyonel (ebeveynlerden) antioksidan kodlayan genler, genç kraliçelerde ve yaş1 1 işçilerde yüksek bulunmuştur (Corona ve ark., 2005). Ancak Parker ve ark. (2004), kraliçe arının ömür uzunluğunun bu bir takım genlerin yüksekliği ile alakalı olmadığını, Corona ve ark. (2005), Lasius niger karıncalarında bazı antioksidanlar için mRNA ve protein seviyeleri bakımından arılar ve karıncaların aynı genetik yapıya sahip olduğunu yapmış oldukları SOD1 bulguları ile göstermişlerdir.

Ek olarak; katalaz, GST (glutation S-transferaz) ve SOD'un, spermlerin canlılıklarını yitirmeksizin birkaç y1l boyunca kraliçelerin spermatekalarında saklama yeteneğine katkıda bulunabildiği öne sürülmüştür (Weirich ve ark., 2002; Collins ve ark., 2004). Katalaz, glutation S-transferaz ve süperoksit dismutaz aktiviteleri, doku homojenatlarının (spermateka, kas ve ventriküllerin) postmitokondriyal fraksiyonlarında, hemolenf plazmasinda ve bal arisi semeninde belirlenmiştir. SOD aktiviteleri (15-59 $\mathrm{mU} / \mathrm{mg})$, dokular arasındaki CAT veya GST aktivitelerinden daha az değişmiştir. Çiftleşmiş kraliçelerin spermatekası içindeki her üç enzimin de önemli aktiviteleri, spermatozoanın oksidatif strese karşı uzun süreli korunmasında yer aldığııı göstermektedir (Weirich ve ark., 2002).

Protein, bal arılarının normal büyümesi ve gelişmesi için gerekli besinlerden biridir (Moritz ve Crailsheim, 1987; Schmidt ve ark., 1995). Polen, bal arılarının gerekli proteinlerini elde etmeleri için doğal ve protein açısından zengin bir besin kaynağıdır (Schäfer ve ark., 2006). Bal arılarında yeterli protein seviyesinin bulunmas1 ömür uzunluğunu etkilemektedir (Knox ve ark., 1971; Burgess ve ark., 1996; Chen, 2001). Araştırmalar, böcek ömrünün antioksidan savunmayla ters orantılı olduğunu bildirmektedir (Phillips ve ark., 1989; Arking ve ark., 2000). Bal arısı orta bağırsağındaki toplam proteaz aktivitesi 
protein sindirimi ile ilgili önemli bir parametredir. Li ve ark. (2012) yaptıkları çalışmada farklı diyet protein konsantrasyonlarının arı gelişimi, gözden yeni çıkan arıların antioksidan seviyesi ve toplam proteaz aktivitesinin midgut etkilerini sistematik olarak değerlendirerek kullandıkları polen içeriklerinin arılar için değerli olduklarını tespit etmişlerdir. Bir koloni için yeterli diyet proteinin sağlanması, yavru yetiştiriciliğini, bireysel arıların ağırlığını, vücut protein içeriğini ve gelişmekte olan işçilerin antioksidan seviyesini iyileştirdiğini, aynı zamanda \% 30-35 protein içeriğine sahip polen ile beslemenin, arı gelişimini teşvik etmek için mükemmel bir diyet olduğunu bildirmiş̧lerdir.

Uzun süren kış mevsimi bal arılarının gıda rezervinin tükenmesine, zayıflamış bireylerin yoğunluğunun artmasına ve hastalıkların kolay yayılmasına yol açabilir (Brodschneider ve Crailsheim, 2010). C vitamininin bağıșı 1 lık üzerindeki faydalı etkisinin bilinmesi Farjan ve ark. (2012)'nı kışlamadaki arılar için besin takviyesi olarak kullandıkları bir çalışma yapmaya teşvik etmiştir. Yapılan çalışmada $\mathrm{C}$ vitamini içerikli diyet takviyelerinin kış döneminde daha az arı kayıplarına yol açtığı belirlenmiştir.

Böceklerde, bitkilere benzer bir glutatyonaskorbik asit (C vitamini) redoks döngüsü (yükseltgenme-indirgenme) aktiftir. $\mathrm{Bu}$ döngü, enzimatik reaksiyonlarda oluşan hidrojen peroksitin verimli bir şekilde atılmasını sağlamaktadır (Summers ve Felton, 1993; Krishnan ve ark., 2009). Bal arılarının $C$ vitamini ihtiyacının tahmin edilmemesine dayanarak, özellikle yapay diyetlerde büyük dozlarda uygulanması önerilmektedir (Herbert ve ark., 1985; Black, 2006).

C vitamini ile yapılan diyet takviyesinin, kovanlardaki daha düşük kış kayıpları ve genç işçi arılarındaki TAS, glutatyon ve antioksidan enzim (peroksidaz, katalaz ve glutatyon transferaz) aktivitesi gibi fizyolojik ve biyokimyasal göstergelerin bazılarını olumlu yönde etkilediği bulunmuştur. Bu bulgular, $\mathrm{C}$ vitamininin kışlayan arılarda ve ilkbahar jenerasyonunun üretilmesinde, stres faktörlerine (oksidatif stresin önemli bir rol oynadığı hastalıklar dahil) karşı direncin arttırılması için doğal, güvenli ve nispeten ucuz bir diyet takviyesi olarak önerilebileceğini göstermektedir (Farjan ve ark., 2012). Reaktif Oksijen Türleri (ROS) olarak görev yapan ve antioksidan enzim olan $\mathrm{Cu} / \mathrm{Zn}$-SOD'un en önemli maddesi olan çinko (Zn), lipit peroksidasyonunu kontrol eden bir antioksidan özelliği göstermektedir. Zhang ve ark. (2015), çalışmalarında, yeterli miktarda Zn diyetinin yüksek $\mathrm{Cu} / \mathrm{Zn}$-SOD aktivitesini sağlayan $\mathrm{Cu} / \mathrm{Zn}$-SOD gen transkripsiyonunu $\operatorname{arttırd}$ ğ 1 sonucuna ulaşmışlardır. Yüksek $\mathrm{Zn}$ diyetlerinin ise bakıcı arılarının hemolenflerindeki $\mathrm{Zn}$ içeriğini sağlayarak arı sütü konsantrasyonunu büyük ölçüde arttırdığını gözlemlemişlerdir. Yapılan bu çalışmaya göre antioksidan durumunu korumak ve işçi arılarının ömür uzunluğunu artırmak amaciyla $\% 50$ 'lik şeker şurubu içerisine $30 \mathrm{mg} \mathrm{kg}^{-1} \mathrm{Zn}$ takviyesi yapılması önerilmektedir. Ayrıca, üretilen arı sütündeki $\mathrm{Zn}$ konsantrasyonunu artırmak ve daha kaliteli larva yetiștirilebilmesini sağlamak amaciyla 60 ile $75 \mathrm{mg} \mathrm{kg}^{-1} \mathrm{Zn}$ içerikli polen kullanılması önerilmektedir.

\section{BAĞIŞIKLIK GENLERİ, DETOKSİIIKASYON ve BESLENME İLIŞKİSi}

Son yıllarda bal arılarının immun cevabını, yön bulma ve öğrenme kabiliyetini baskılayan pestisitlere ve patojenlere maruz kalması ve besinsel yetersizlik sonucu gözlenen koloni kayıpları sonucunda yapılan araştırmalar bal arılarının diğer böceklere nazaran kısıtlı detoksifikasyon ilişkili genlere sahip olduğunu öne sürmüştür (Claudianos ve ark., 2006; Mao ve ark., 2013).

Faz 1 detoksifikasyon enzimleri arasında olan cytochrome P450 monoksijenaz (P450s), insektisistleri, balda ve polende bulunan fitokimyasalları (bitkilerde bulunan doğal birleşikler) içeren toksinleri ve Varroa destructor ile mücadelede kullanılan akarisitleri metobolize ederek detoksifikasyonda önemli rol oynayan bir enzimdir (Mao ve ark., 2013; Esther ve ark., 2015, Zhang ve ark., 2019). Bal arılarında bal içeriğinde bulunan $p$-kumarik asit, pinocembrin ve pinobanksin 5-methyl ether gibi fenolik asitlerin detoksifikasyon genlerini uyardığı gözlenmiştir. 
Özellikle $p$-kumarik asit nektar içinde bulunmamasına rağmen polen/arı ekmeği içeriğinde gözlenmiştir. Araştırmalara göre özellikle polen taneciklerinin dış duvarında bulunan $p$-kumarik asit, antimikrobiyel peptit genlerinin seçilmesinde ve patojen ile pestisitlere karşı koruma mekanizmasında gerekli olan çeşitli detoksifikasyon genlerinin etkinliğinin arttırılmasında önemli bir rol oynamaktadır (Wehling ve ark., 1989; Mao ve ark., 2013).

Mao ve ark. (2013), akarisit olan coumaphosun varlığını kontrol etmek amaciyla iki besleme denemesinden biri olan $p$-kumarik asit konsantrasyonu içeren şeker şurubu ve diğeri normal şeker şurubu uygulamışlardır. Denemede kullanılan bal arıların midgutları çıkartılmıştır ve RNA sekanslama (RNA seq) analizi ile $p$-kumarik asitin patojen ve pestisitlere karşı savaşmak için gerekli olan detoksifikasyon genlerini [Cytochrome P450 monooxygenases (P450s)] arttırdığ gözlenmiştir. $\mathrm{Bu}$ araştırma sonucunda kolonilerin patojen ve pestisitler ile savaşma mekanizmalarının güçlendirilmesi amacı ile $p$ kumarik asit'in takviye ek besin maddesi olarak kullanılabileceğini önermişlerdir.

Yapılan bir araştırmada, propolis içeren ve içermeyen polen diyeti ile beslenen ve Escherichia coli ile enfekte edilmiş iş̧̧i arıların antimikrobiyal peptitleri kodlayan genleri analiz edilmiştir. Propolis $(\% 0,1)$ içeren diyet ile beslenen enfekte olmuş arılarda antimikrobiyal protein gen ekspresyonu (defensin-1, abaecin ve hymenoptaecin) oldukça artarken enfekte olmayan arılarda ise herhangi bir değişim gözlenmemiştir. $\mathrm{Bu}$ durum da propolis içeren diyetle beslenmenin arıların immun sistemini bakteriye maruz kaldığında aktif hale getirdiği sonucunu göstermektedir (Turcatto ve ark., 2018).

\section{SONUC}

Beslenme stresi ve patojenler arasındaki etkileşim kolonilerde ve kolonideki iş bölümünde ciddi dengesizliklere neden olabilir (Dolezal ve Toth,
2018). Ciddi kayıplara neden olan stres faktörleri arasındaki etkileşim ile mücadele edebilmek çok önemlidir. Yüksek miktarda virüs enfeksiyonlarının açığa çıkmasında en büyük etken kolonilerin Varroa yükünün artmasıdır (Francis ve Kryger, 2012). Yetersiz beslenen koloniler özellikle Varroa istilasına karşı daha duyarlıdır (Ellis, 2007). KÇS'nin ortaya çıkmasında hem besleme yetersizlikleri hem de patojenlerin var olması önemli rol oynamaktadır (Suryanarayanan ve Kleinman, 2016). Bal arılarının varlığ 1 ve sağllğ hem insanlar hem de ekoloji için önemli olmasından dolayı KÇS'nin meydana gelme sebebinin belirlenmesi ve bunun için önlemler alınması çok kritik bir önem taşımaktadır (Anonymous, 2016; Suryanarayanan ve Kleinman, 2016).

Yetiştiricilik açısından özellikle arıcılıkta güçlü kolonilerin varlı̆̆ 1 kışlama öncesi kolonilerin durumuna da bağlıdır. Kışlama öncesi kovanlarda yeterli ballı ve polenli peteklerin birakılması gerekmektedir. Kışlatmaya her zaman genç arılarla girilmesi kış kaybını azaltacaktır. Kovanlardaki arı ürünleri sadece arıcılar tarafindan değerlendirilmemeli aynı zamanda koloninin yaşaması için arı ile de paylaşılmalıdır. İklimsel değişimler nedeniyle floral kaynaklarda yaşanacak olumsuzluklara karşı arıların beslenmesi kolonin devamlılığı için gereklidir. Arıcılar genelde ilkbahar ve sonbahar mevsimlerinde ucuz ve düşük proteinli anı keklerine yönelse de, arı kolonilerini zirai ilaç kalıntısı bulunmayan polen veya yüksek proteinli polen ikame yemleriyle beslemeyi tercih etmelidir. Arılıklarında özellikle arıların tercih ettikleri bitkilerin yetiştiriciliğinin yapılması beslenme, iklim değişimleri, polen toplama ve arıcı ekonomisi açısından önemlidir.

Sonuç olarak; arıcılıkta doğru ve yeterli besleme; hastalık ve zararlılarla etkin mücadele, gereksiz ilaç kullanımından kaçınılması ve dolayısıyla arı ürünlerinde kalıntı sorunu gibi birçok problemin çözümünde ve sürdürülebilir arıcılık için kilit noktalarından birini oluşturacaktır. 


\section{LITTERATÜR LISTESI}

Ababouch, L., A. Chaibi, and F. F. Busta. 1992. Inhibition of bacterial spore growth by fatty acids and their sodium salts. Journal of Food Protection 55 (12): 980-984.

Alaux, C., F. Ducloz, D. Crauser, and Y. Le Conte. 2010. Diet effects on honeybee immunocompetence. Biology Letters 6 (4): 562-565.

Alhaddad, S., and B. Darchen. 1995. The influence of meteorological conditions on the feeding and egg laying of the queen honey bee [Apis mellifera ligustica]. Comptes Rendus de l'Academie des Sciences Serie 3 Sciences de la Vie (France) 318 (2): 245-248.

Allsopp, M., R. Tirado, P. Johnston, D. Santillo, and P. Lemmens. 2014. Plan bee-living without pesticides moving towards ecological farming. Greenpeace International, Amsterdam. Available at https://www. greenpeace.org/international/ publication/7380/plan-beeliving-without-pesticides/Erişim tarihi; 26.12.2019.

Amdam, G. V., K. Norberg, A. Hagen, and S. W. Omholt. 2003. Social exploitation of vitellogenin. Proceedings of the National Academy of Sciences 100 (4): 17991802.

Amdam, G. V., K. Hartfelder, K. Norberg, A. Hagen, and S. W. Omholt. 2004. Altered physiology in worker honey bees (Hymenoptera: Apidae) infested with the mite Varroa destructor (Acari: Varroidae): a factor in colony loss during overwintering? Journal of Economic Entomology 97 (3): 741-747.

Anonymous. 2016. IPBES. The assessment report of the Intergovernmental Science-Policy Platform on Biodiversity and Ecosystem Services on pollinators, pollination and food production. S. G. Potts, V. L. Imperatriz-Fonseca, and H. T. Ngo (Eds.). Secretariat of the Intergovernmental Science-Policy Platform.

Arai, R., K. Tominaga, M. Wu, M. Okura, K. Ito, N Okamura, H. Onishi, M. Osaki, Y. Sugimura, M. Yoshiyama, and D. Takamatsu. 2012. Diversity of Melissococcus plutonius from Honeybee Larvae in Japan and Experimental Reproduction of European Foulbrood with Cultured Atypical Isolates. PLoS ONE 7 (3): e33708. https://doi.org/10.1371/journal. pone.0033708.

Arking, R., V. Burde, K. Graves, R. Hari, E. Feldman, and A. Zeevi. 2000. Forward and reverse selection for longevity in Drosophila is characterized by alternation of antioxidant gene expression and oxidative damage patterns. Exp. Gerontol. 35: 167-185.

Aronstein, K. A., E. Saldivar, R. Vega, S. Westmiller, and A. E. Douglas. 2012. How Varroa parasitism affects the immunological and nutritional status of the honey bee, Apis mellifera. Insects 3 (3): 601-615.

Arrese, E. L., and J. L. Soulages. 2010. Insect fat body: energy, metabolism, and regulation. Annual Review of Entomology 55: 207-225.
Black, J. 2006. Honey bee nutrition. Review of research and practices. A report for the Rural Industries Research and Developmental Corporation. Australian Government. RIRDC Publication No 06/052, 67 p.

Brodschneider, R., and K. Crailsheim. 2010. Nutrition and health in honey bees. Apidologie 41 (3): 278-294.

Burgess, E. P. J., L. A. Malone, and J. T. Christeller. 1996. Effects of two proteinase inhibitors on the digestive enzyme. J. Insect Physiol. 42: 823-828.

Burrill, R. M., and A. Dietz. 1981. The response of honey bees to variations in solar radiation and temperature. Apidologie 12 (4): 319-328.

Candy, D. J., A. Becker, and B. Wegener. 1997. Coordination and integration of metabolism in insect flight. Comparative Biochemistry and Physiology. 117B: 497-512. http://doi.org/10.1016/S0305-0491(97)00212-5.

Chen, S. L. 2001. The apicultural science in china. China Agricultural Press, Beijing.

Claudianos, C., H. Ranson, R.M. Johnson, S. Biswas, M. A. Schuler, and M. R. Berenbaum, , R. Feyereisen\& and J.G. Oakeshott. 2006. A deficit of detoxification enzymes: pesticide sensitivity and environmental response in the honeybee. Insect Molecular Biology 15 (5): 615-636.

Collins, A. M., V. Williams, and J. D. Evans. 2004. Sperm storage and antioxidative enzyme expression in the honey bee, Apis mellifera. Insect Molecular Biology 13 (2): 141-146. https://doi.org/10.1111/j.0962-1075.2004.00469.x.

Corona, M., K. A. Hughes, D. B. Weaver, and G. E. Robinson. 2005. Gene expression patterns associated with queen honey bee longevity. Mechanisms of Ageing and Development 126 (11): 1230-1238. https://doi.org/ 10.1016/j.mad.2005.07.004.

Cox-Foster, D., Y. Chen, R. Underwood, D. R. Tarpy, and J. S. Pettis. 2009. Colony collapse disorder: A descriptive study. PLoS ONE 4: e6481Da silva, J. G. 2018. Food and Agriculture Organization of United Nations. http://www.fao.org/pollination/en/.

DeGrandi-Hoffman, G., and Y. Chen. 2015. Nutrition, immunity and viral infections in honey bees. Current Opinion in Insect Science 10: 170-176.

DeGrandi-Hoffman, G., Y. Chen, E. Huang, and M. H. Huang. 2010. The effect of diet on protein concentration, hypopharyngeal gland development and virus load in worker honey bees (Apis mellifera L.). Journal of insect physiology 56 (9): 1184-1191.

DeGrandi-Hoffman, G., S. L. Gage, V. Corby-Harris, M. Carroll, M. Chambers, H. Graham, C. Meador. 2018. Connecting the nutrient composition of seasonal pollens with changing nutritional needs of honey bee (Apis mellifera L.) colonies. Journal of Insect Physiology 109: 114-124. 
Di Pasquale, G., M. Salignon, Y. Le Conte, L. P. Belzunces, A. Decourtye, A. Kretzschmar, C. Alaux. 2013. Influence of pollen nutrition on honey bee health: do pollen quality and diversity matter? PloS one 8 (8): e72016.

Dolezal, A. G., and A. L. Toth. 2018. Feedbacks between nutrition and disease in honey bee health. Current Opinion in Insect Science 26: 114-119.

Dolezal, A. G., J., Carrillo-Tripp, T. M. Judd, W. Allen Miller, B.C. Bonning, and A. L. Toth. 2019. Interacting stressors matter: diet quality and virus infection in honeybee health. Royal Society Open Science 6 (2): 181803. https://dx.doi.org/10.6084/m9.figshare.

Ellis, J. 2007. Colony collapse disorder (CCD) in honey bees. University of Florida, Cooperative Extension Service.

Esther, E., S. Smit, M. Beukes, Z. Apostolides, C. W. Pirk, and S. W. Nicolson. 2015. Detoxification mechanisms of honey bees (Apis mellifera) resulting in tolerance of dietary nicotine. Scientific Report. 5: 11779.

Farjan, M., M. Dmitryjuk, Z. Lipiński, E. Biernat-Łopieńska, and K. Żółtowska. 2012. Supplementation of the honey bee diet with vitamin C: The effect on the antioxidative system of Apis mellifera carnica brood at different stages. Journal of Apicultural Research 51 (3): 263-270. https://doi.org/10.3896/ibra.1.51.3.07.

Feldlaufer, M. F., D. A. Knox, W. R. Lusby, and H. Shimanuki. 1993. Antimicrobial activity of fatty acids against Bacillus larvae, the causative agent of American foulbrood disease. Apidologie 24 (2): 9599. https://doi.org/10.1051/apido:19930202.

Ferguson, J. A., T. D. Northfield, and L. Lach. 2018. Honey Bee (Apis mellifera) Pollen foraging reflects benefits dependent on individual infection status. Microbial Ecology 76 (2): 482-491.

Fleming, J. C., D. R. Schmehl, and J. D. Ellis. 2015. Characterizing the Impact of commercial pollen substitute diets on the level of Nosema spp. in honey bees (Apis mellifera L.). PLoS ONE 10(7): e0132014. https://doi.org/10.1371/journal.pone.0132014

Francis, R. M., and P. Kryger. 2012. Single assay detection of acute bee paralysis virus, kashmir bee virus and israeli acute paralysis virus. Journal of Apicultural Science 56: 137-146.

Genersch, E. 2010. American Foulbrood in honeybees and its causative agent, Paenibacillus larvae. Journal of invertebrate pathology 103: S10-S19.

Giacomini, J. J., J. Leslie, D. R. Tarpy, E. C. Palmer-Young, R. E. Irwin, and L. S. Adler. 2018. Medicinal value of sunflower pollen against bee pathogens. Scientific reports 8 (1): 14394.
Gumusova, S. O., H. Albayrak, M. Kurt, and Z. Yazici. 2010. Prevalence of three honey bee viruses in Turkey. Veterinarski Arhiv. 80 (6): 779-785.

Heard, T. A., and J. K. Hendrikz. 1993. Factors influencing flight activity of colonies of the stingless bee Trigona carbonaria (Hymenoptera, Apidae). Australian Journal of Zoology 41 (4): 343-353.

Hendriksma, H. P., C. D. Pachow, and J. C. Nieh. 2019. Effects of essential amino acid supplementation to promote honey bee gland and muscle development in cages and colonies. Journal of Insect Physiology Vol. 117. 103906. https://doi.org/10.1016/j.jinsphys.2019. 103906.

Herbert, E. W., W. E. Bickley, and H. Shimanuki. 1970. The brood-rearing capability of caged honey bees fed dandelion and mixed pollen diets. J. Economic Entomology 63: 215-218.

Herbert, E. W., J. T. Vanderslice, and D. J. Higgs. 1985. Vitamin $\mathrm{C}$ enhancement of brood rearing bycaged honeybees fed a chemically defined diet. Archives of Insect Biochemistry and Physiology 2: 29-37.

Hornitzky, M. A. Z. 2003. Fatty acids - An alternative control strategy for honey bee diseases, $23 \mathrm{pp}$. Barton, ACT: Rural Industries Research and Development Corporation, Australia.

Höcherl, N., R. Siede, I. Illies, H. Gätschenberger, and J. Tautz. 2012. Evaluation of the nutritive value of maize for honey bees. J. Insect Physiology 58: 278-285.

Huang, Z. 2012. Pollen nutrition affects honey bee stress resistance. Terrestrial Arthropod Reviews 5 (2): 175189.

Janmaat, A. F., and M. L. Winston. 2000. The influence of pollen storage area and Varroa jacobsoni Oudemans parasitism on temporal caste structure in honey bees (Apis mellifera L.).Insectes Sociaux 47 (2): 177-182. https://doi.org/10.1007/PL00001698.

Kasper, M. L., A. F. Reeson, D. A. Mackay, and A. D. Austin. 2008. Environmental factors influencing daily foraging activity of Vespula germanica (Hymenoptera, Vespidae) in Mediterranean Australia. Insectes Sociaux. 55 (3): 288-295.

Karacoban, T. 2018. Viral prevalence among social bees in different landscapes. MS thesis. University of Nebraska.

Knox, D. A., H. Shimanuki, and E. W. Herbert. 1971. Diet and the longevity of adult honey bees. J. Econ. Entomol. 64: 1415-1416.

Krishnan, N., D. Kodrik, B. Kludkiewicz, and F. Sehnal. 2009. Glutathione-ascorbic acid redox cycle and thioredoxin reductase activity in the digestive tract of Leptinotarsa decemlineata (Say). Insect Biochemistry and Molecular Biology 39: 180-188. https://doi.org/10.1016/j.ibmb. 2008.11.001. 
T. OLGUN, E. TOPAL, N. GÜNES, D. OSKAY, A. SARIOĞLU: BAL ARILARINDA (Apis mellifera L.) BESLENMENIN HASTALIK VE ZARARLILARLA İLIŞKISII

Kuzyšinová, K., D. Mudroňová, J. Toporčák, L. Molnár, and P. Javorský. 2016. The use of probiotics, essential oils and fatty acids in the control of American foulbrood and other bee diseases. Journal of Apicultural Research 55 (5): 386-395.

Li, C., B. Xu, Y. Wang, Q. Feng, and W. Yang. 2012. Effects of dietary crude protein levels on development, antioxidant status, and total midgut protease activity of honey bee (Apis mellifera ligustica). Apidologie 43 (5): 576-586. https:// doi.org/10.1007/s13592-012-0126-0.

Loper, G. M., and A. C. Cohen. 1987. Amino acid content of dandelion pollen, a honey bee (Hymenoptera: Apidae) nutritional evaluation. J. Econ. Entomol. 80: 14-17. https:// doi.org/10.1093/jee/80.1.14.

Manning, R. 2001. Fatty acids in pollen: a review of their importance for honey bees, Bee World 82 (2): 60-75. https:// doi.org/10.1080/0005772X.2001.11099504.

Mao, W., M. A. Schuler, and M. R Berenbaum. 2013. Honey constituents up-regulate detoxification and immunity genes in the western honey bee Apis mellifera. Proceedings of the National Academy of Sciences 110 (22): 8842-8846.

McMenamin, A. J., and Flenniken, M. L. 2018. Recently identified bee viruses and their impact on bee pollinators. Current Opinion in Insect Science 26: 120129. https:// doi.org/10.1016/j.cois.2018.02.009.

Morawetz, L., H. Köglberger, A. Griesbacher, I. Derakhshifar, K. Crailsheim, R. Brodschneider, and R. Moosbeckhofer. 2019. Health status of honey bee colonies (Apis mellifera) and disease-related risk factors for colony losses in Austria. PloS one 14 (7): e0219293.

Morimoto, T., Y. Kojima, T. Toki, Y. Komeda, M. Yoshiyama, K. Kimura, K. Nirasawa, and T. Kadowaki. 2011. The habitat disruption induces immune - suppression and oxidative stress in honey bees. Ecology and Evolution 1 (2): 201-217.

Moritz, B., and K. Crailsheim. 1987. Physiology of protein digestion in the midgut of the honeybee (Apis mellifera L.). Journal of Insect Physiology 33 (12): 923-931.

Naug, D. 2009. Nutritional stress due to habitat loss may explain recent honeybee colony collapses. Biological Conservation 142 (10): 2369-2372.

Naug, D., and A. Gibbs. 2009. Behavioral changes mediated by hunger in honeybees infected with Nosema ceranae. Apidologie. 40 (6): 595-599.

Nürnberger, F., S. Härtel, and I. Steffan-Dewenter. 2019. Seasonal timing in honey bee colonies: phenology shifts affect honey stores and varroa infestation levels. Oecologia. 189 (4): 1121-1131.
Oldroyd, B. P. 2007. What's killing American honey bees? Plos Biology 5 (6): e168. https://doi.org /10.1371/ journal.pbio.0050168.

Oskay, D. 2017. Bal arısı ek beslemesinde sorunlar ve çözüm önerileri. Arıcılık Araştırma Dergisi 9 (1): 1-8.

Page, R. E. Jr, and C. Y. Peng. 2001. Aging and development insocial insects with emphasis on the honey bee, Apis mellifera L. Exp Gerontol. 36 (4-6): 695-711. https://doi.org/10.1016/S0531-5565(00)00236-9.

Paris, L., H. El Alaoui, F. Delbac, and M. Diogon. 2018. Effects of the gut parasite Nosema ceranae on honey bee physiology and behavior. Current Opinion in İnsect Science. 26: 149-154.

Parker, J. D., K. M. Parker, B. H. Sohal, R. S. Sohal, and L. Keller. 2004. Decreased expression of $\mathrm{Cu}-\mathrm{Zn}$ superoxide dismutase 1 in ants with extreme lifespan. Proceedings of the National Academy of Sciences 101 (10): 3486-3489.

Phillips, J. P., S. D. Campbell, D. Michaud, M. Charbonneau, and A. J. Hilliker. 1989. Null mutation of copper/zinc superoxide dismutase in Drosophila confers hypersensitivity to paraquat and reduced longevity. Proc. Natl. Acad. Sci. (USA) 86: 2761-2765.

Piou, V., J. Tabart, J. L. Hemptinne, and A. Vétillard. 2018. Effect of pollen extract supplementation on the varroatosis tolerance of honey bee (Apis mellifera) larvae reared in vitro. Experimental and Applied Acarology 74 (1): 25-41.

Porrini, M. P., E. G. Sarlo, S. K. Medici, P. M. Garrido, D. P. Porrini, N. Damiani, and M. J. Eguaras. 2011. Nosema ceranae development in Apis mellifera: influence of diet and infective inoculum. Journal of Apicultural Research 50 (1): 35-41.

Potts, S. G., J. C. Biesmeijer, C. Kremen, P. Neumann, O. Schweiger, and W. E. Kunin. 2010. Global pollinator declines: trends, impacts and drivers. Trends in Ecology \& Amp; Eevolution 25 (6): 345-353.

Ramsey, S. D., R. Ochoa, G. Bauchan, C. Gulbronson, J. D. Mowery, A. Cohen, and D. Hawthorne. 2019. Varroa destructor feeds primarily on honey bee fat body tissue and not hemolymph. Proceedings of the National Academy of Sciences 116 (5): 1792-1801.

Rinderer, T. E., and K. Dell Elliott. 1977. Worker honey bee response to infection with Nosema apis: influence of diet. Journal of Economic Entomology 70 (4): 431433.

Schäfer, M. O., V. Dietemann, C. W. W. Pirk, P. Neumann, R. M. Crewe, H. R. Hepburn, J. Tautz, and K. Crailsheim. 2006. Individual versus social pathway to honeybee worker reproduction (Apis mellifera): pollen or jelly as protein source for oogenesis. J. Comp. Physiol. A. 192: 761-768. 
Schmidt, L. S., J. O. Schmidt, R. Hima, W. Y. Wang, and L. G. Xu. 1995. Feeding preference and survival of young worker honey bees (Hymenoptera: Apidae) fed rape, sesame, and sunflower pollen. Journal of Economic Entomology 88: 1591-1595.

Seehuus, S. C., K. Norberg, U. Gimsa, T. Krekling, and G. V. Amdam. 2006. Reproductive protein protects functionally sterile honey bee workers from oxidative stress. Proc Natl Acad Sci U S A. 103: 962-967. https://doi.org/10.1073/pnas.0502681103.

Summers, C., and G. W. Felton. 1993. Antioxidant role of dehydroascorbic acid reductase in insects. Biochimica et Biophysica Acta. 1156: 235-238. http://dx.doi.org/ 10.1016/0304-4165(93)90142-U.

Suryanarayanan, S., and D. L. Kleinman. 2016. Vanishing Bees: Science, Politics, and Honeybee Health. Rutgers University Press.

Switanek, M., K. Crailsheim, H. Truhetz, and R. Brodschneider. 2017. Modelling seasonal effects of temperature and precipitation on honey bee winter mortality in a temperate climate. Science of the Total Environment 579: 1581-1587.

Szabo, T. I. 1980. Effect of weather factors on honeybee flight activity and colony weight gain. Journal of Apicultural Research 19 (3): 164-171.

Thuiller, W., S. Lavorel, M. B. Araujo, M. T. Sykes, and I. C. Prentice. 2005. Climate change threats to plant diversity in Europe. Proceedings of the National Academy of Sciences (PNAS) 102 (23): 8245-8250. https://doi.org/10.1073/pnas.0409902102.

Traynor, K. S., K. Rennich, E. Forsgren, R. Rose, J. Pettis, G. Kunkel, S. Madella, J. Evans, D. Lopez, and D. vanEngelsdorp. 2016. Multiyear survey targeting disease incidence in US honey bees. Apidologie 47: 325-347.

Turcatto, A. P., A. P. Lourenço, and D. De Jong. 2018. Propolis consumption ramps up the immune response in honey bees infected with bacteria. Apidologie 49 (3): $287-296$
VanEngelsdorp, D., and M. D. Meixner. 2010. A historical review of managed honey bee populations in Europe and the United States and the factors that may affect them. Journal of Invertebrate Pathology 103: 80-95.

VanEngelsdorp, D., N. Speybroeck, J. D. Evans, B. K. Nguyen, C. Mullin, M. Frazier, J. Frazier, D. CoxFoster, Y. Chen, D. R. Tarpy, E. Haubruge, J. S. Pettis, and C. Saegerman. 2010. Weighing risk factors associated with bee colony collapse disorder by classification and regression tree analysis. Journal of Eeconomic Eentomology 103 (5): 1517-1523.

Vicens, N., and J. Bosch. 2000. Weather-dependent pollinator activity in an apple orchard, with special reference to Osmia cornuta and Apis mellifera (Hymenoptera: Megachilidae and Apidae). Environmental Entomology 29 (3): 413-420.

Wehling, K., Ch. Niester, J. J. Boon, M. T. M. Willemse, and R. Wiermann. 1989. $p$ - Coumaric acid - a monomer in the sporopollenin skeleton. Planta 179: 376-380. https://doi.org/10.1007/BF00202338.

Weirich, G. F., A. M. Collins, and V. P. Williams. 2002. Antioxidant enzymes in the honey bee, Apis mellifera. Apidologie 33: 3-14

Winston, M. L. 1987. The biology of the honey bee. Harvard University Press, Cambridge, Massachusetts.

Zhang, G., W. Zhang, X. Cui, and B. Xu. 2015. Zinc nutrition increases the antioxidant defenses of honey bees. Entomologia Experimentalis et Applicata 156 (3): 201-210.

Zhang, X., J. Dong, H. Wu, H. Zhang, J. Zhang, and E. Ma. 2019. Knockdown of cytochrome P450 CYP6 family genes increases susceptibility to carbamates and pyrethroids in the migratory locust, Locusta migratoria. Chemosphere 223: 48-57. https://doi.org/ 10.1016/j.chemosphere.2019.02.011. 